\title{
GINGER AND TEMULAWAK BASED HERBAL TEA AS POTENTIAL FUNCTIONAL DRINK PRODUCTS IN THE ERA OF COVID-19
}

\author{
N. Kusumawati ${ }^{1,}$, A. Bahar ${ }^{2}$, P. Setiarso ${ }^{1}$, S. Muslim ${ }^{3}$ and A.R.S. Auliya ${ }^{4}$ \\ ${ }^{1}$ Department of Chemistry, Faculty of Mathematics and Science, Universitas Negeri Surabaya, \\ Surabaya, Indonesia, 60231. \\ ${ }^{2}$ Department of Family Welfare Education, Faculty of Engineering, Universitas Negeri \\ Surabaya, Surabaya, Indonesia, 60231. \\ ${ }^{3}$ Department of Electrical Engineering, Faculty of Engineering, Universitas Negeri Surabaya, \\ Surabaya, Indonesia, 60231. \\ ${ }^{4}$ Department of Chemistry, Faculty of Science and Technology, Airlangga University, Surabaya, \\ Indonesia, 60115. \\ ${ }^{\otimes}$ Corresponding Author: nitakusumawati@unesa.ac.id
}

\begin{abstract}
To optimize the benefits of herbal processed products, especially in the era of the COVID-19 pandemic, an evaluation of the antioxidant and antimicrobial functional properties of herbal teas has been carried out. The ginger and temulawak herbal tea products in this study showed the quality that met the qualifications of the Indonesian National Standard (SNI) 3836:2013, with low levels of metal and microbial contamination and high antioxidant and antimicrobial activity against Escherichia coli and Salmonella Typhimurium. In general, the ginger and temulawak teas produced have a distinctive taste, aroma, color, and texture, with a water content of 7.26-7.61\%, ash 6.12 $6.71 \%$, water-soluble ash $95.48-97.01 \%$, acid insoluble ash $0.160-0.275 \%$, crude fiber $4.63-14 \%$, phenolic $66.15-$ $95.58 \%$, flavonoids $36.53-67.10 \%$.
\end{abstract}

Keywords: Herbal, Tea, Functional Drink, Ginger, Temulawak.

RASĀYAN J. Chem., Vol. 14, No.3, 2021

\section{INTRODUCTION}

Severe acute respiratory syndrome-coronavirus-2 (SARS-CoV-2) is a new corona- $\beta$ virus that is responsible for COVID-19. ${ }^{1-2}$ As of April 24, 2020, the overall outbreak has caused more than 191,000 deaths and an estimated 2,700,000 infected worldwide. ${ }^{2-3}$ COVID-19 provokes a wide spectrum of clinical manifestations, which lead to acute respiratory distress syndrome (ARDS). ${ }^{2,4-5}$ Although several interventions have been reported, both in prevention and treatment, none have been proven to be effective against COVID-19.

A large number of the world's population depends on herbal commodities for primary health needs. ${ }^{6-8}$ Herbal drinks are a form of herbal-based health care and medicine that produce a broad spectrum of biological activity, inducing positive effects in the treatment of many diseases. ${ }^{9}$

Ginger and temulawak are widely used as functional ingredients in herbal beverages production worldwide. Ginger (Zingiber officinale) is reported to have antioxidant, antimicrobial, and antiinflammatory activity. ${ }^{10-13}$ Temulawak (Curcuma zanthorrhiza Roxb) is a rhizomatous herb containing xanthorrhizol which is reported to have anti-cancer, anti-microbial, anti-inflammation, anti-oxidant, antihyperglycemic, antihypertensive, antiplatelet activity, nephroprotective, hepatoprotective, and estrogenic effects. ${ }^{14-25}$

In this research, ginger and temulawak are processed into practical teabags through a series of standardized production stages. The increased practicality of consumption and the taste of the ginger and 
temulawak processed products is expected to encourage more people who are willing to consume regularly, to increase endurance in the era of the COVID-19 pandemic.

\section{EXPERIMENTAL}

\section{Making of Ginger Tea}

The ginger was cleaned, sliced $0.15 \mathrm{~cm}$ thick using a Bosch MUZ4DS3 slicing machine, weighed, and placed thinly on a baking sheet. Drying was carried out using an oven at $60^{\circ} \mathrm{C}$ until a constant mass was obtained. For ginger tea products made from elephant ginger, a ratio of ginger simplicia to tea leaves was $5: 1$, while for those made from emprit ginger, a ratio of ginger simplicia to tea leaves was $2: 1$. In a different place, the production of temulawak tea products was carried out with the same procedure, with a ratio of temulawak simplicia to tea leaves of 1:1.

\section{Herbal Tea Quality Test}

The quality testing of herbal teas includes (1) organoleptic, proximate, and crude fiber using the gravimetric method; (2) total flavonoids, phenolic, antioxidant activity using the UV-Vis spectrophotometric method; (3) antimicrobial activity using the diffusion method with the cup plate technique.

\section{Physico-chemical Properties}

\section{RESULTS AND DISCUSSION}

The herbal tea produced has a distinctive taste and aroma, with a creamy color for ginger, and a yellowish-brown for temulawak tea. The organoleptic properties of both herbal teas meet the requirements of the SNI 3836:2013.

The water content greatly affects the dry tea shelf life. Dry teas with high water content tend to be moist and perishable. The water content analysis showed that the ginger tea from both raw materials showed a lower water content than that of temulawak. This is consistent with Wiranata's (2016) publication which reports that fresh temulawak has a higher water content (86\%) than the elephant and emprit ginger, which were $71.15 \%$ and $70.31 \%$, respectively. ${ }^{26-27}$

Table-1: Physico-chemical Properties of Herbal Tea

\begin{tabular}{c|c|c|c|c|c|c|c|c|c|c}
\hline \multirow{2}{*}{$\begin{array}{c}\text { Raw } \\
\text { Material }\end{array}$} & Taste & Smell & Color & Texture & Shape & Water & Ash & $\begin{array}{c}\text { Water- } \\
\text { soluble } \\
\text { Ash }\end{array}$ & $\begin{array}{c}\text { Acid } \\
\text { Insoluble } \\
\text { Ash }\end{array}$ & $\begin{array}{c}\text { Crude } \\
\text { Fiber } \\
(\%)\end{array}$ \\
\hline $\begin{array}{c}\text { Standard } 2 \\
\text { (SNI } \\
3836: 2013)\end{array}$ & $\begin{array}{c}\text { Tea } \\
\text { distinctive }\end{array}$ & $\begin{array}{c}\text { Tea } \\
\text { distinctive }\end{array}$ & $\begin{array}{c}\text { Dark } \\
\text { chocolate }\end{array}$ & - & - & $\begin{array}{c}\text { Max. } \\
8\end{array}$ & $\begin{array}{c}\text { Max. } \\
8\end{array}$ & $\begin{array}{c}\text { Min. } \\
45\end{array}$ & $\begin{array}{c}\text { Max. } \\
1.0\end{array}$ & $\begin{array}{c}\text { Max. } \\
16.5\end{array}$ \\
\hline $\begin{array}{c}\text { A }= \\
\text { Elephant } \\
\text { Ginger }\end{array}$ & $\begin{array}{c}\text { Ginger } \\
\text { distinctive }\end{array}$ & $\begin{array}{c}\text { Ginger } \\
\text { distinctive }\end{array}$ & Cream & Rough & Flakes & 7.26 & 6.44 & 95.48 & 0.170 & 5.43 \\
\hline $\begin{array}{c}\text { B Emprit } \\
\text { Ginger }\end{array}$ & $\begin{array}{c}\text { Ginger } \\
\text { distinctive }\end{array}$ & $\begin{array}{c}\text { Ginger } \\
\text { distinctive }\end{array}$ & Cream & Rough & Flakes & 7.49 & 6.12 & 97.01 & 0.275 & 4.63 \\
\hline $\begin{array}{c}\mathrm{C}= \\
\text { Temulawak }\end{array}$ & $\begin{array}{c}\text { Temulawak } \\
\text { distinctive }\end{array}$ & $\begin{array}{c}\text { Temulawak } \\
\text { distinctive }\end{array}$ & $\begin{array}{c}\text { Yellowish- } \\
\text { brown }\end{array}$ & Rough & Flakes & 7.61 & 6.71 & 95.48 & 0.160 & 14.00 \\
\hline
\end{tabular}

Ash is an inorganic residue that results from burning organic material. Ginger tea shows lower ash content than temulawak tea. Specifically, the tea produced from elephant and emprit ginger had an ash content of $6.44 \%$ and $6.12 \%$, respectively, while temulawak tea was $6.71 \%$. The ash content of fresh ginger was reported to be $6.60-7.57 \%$ for elephant ginger and $7.39-8.90 \%$ for emprit ginger. ${ }^{28}$ Meanwhile, fresh temulawak ash content reported was 5.26-7.07\%. ${ }^{29-30}$ Although it is reported to have lower ash content in its fresh ingredients, tea produced from elephant ginger is known to have higher ash content. This was triggered by the dominance of non-volatile minerals in elephant ginger compared to emprit ginger. Similar conditions also cause temulawak tea to have higher ash content than ginger. 
RASĀYAN J. Chem.

Vol. 14 | No. 3 |1920-1926| July - September | 2021

Acid insoluble ash is closely related to mineral content, purity, and cleanliness of foodstuffs. ${ }^{31-32}$ The results in Table-1 show that the acid insoluble ash content of all herbal tea is less than $1 \%$. Specifically, tea produced from emprit ginger has higher acid insoluble ash content than elephant ginger. This result is predicted to be closely related to the higher contamination level of fresh emprit ginger compared to elephant ginger. Temulawak tea has lower acid-insoluble ash content than ginger. This shows the dominance of the acid-soluble mineral in fresh temulawak.

In contrast, water-soluble ash content indicates the mineral content that can dissolve in water. According to SNI 3836:2013, the required water-soluble ash content in dry tea is at least $45 \%$. All herbal tea produced has met the requirements. Specifically, herbal tea produced from emprit ginger had the highest water-soluble ash.

In the publication of McDonald et al. (2002), fiber is the cell wall of plant tissue which includes lignin, cellulose, and hemicellulose, while crude fiber is composed of $50-80 \%$ of total cellulose, $10-15 \%$ lignin, and 20\% hemicellulose. ${ }^{33-35}$ The results of crude fiber analysis showed that the temulawak tea had higher crude fiber than ginger. However, it should be noted that too high crude fiber content can have an impact on the digestibility of food products after consumption. When crude fiber is too high, food will stay in the stomach system longer, resulting in lower food intake. Overall, the herbal tea produced has met the SNI requirements, which is lower than $16.5 \%$.

\section{Total Phenolic and Flavonoid Compound}

Phenolic are compounds that have one or more hydroxyl groups attached to aromatic groups. ${ }^{36-38}$ This compound has several biological effects such as antioxidant activity through mechanisms as reducing and scavenging of free radicals, metal chelating, reducing singlet oxygen formation, and electron donors. ${ }^{39}$ Meanwhile, flavonoids are a group of polyphenolic compounds in fruits, vegetables, tea, and medicinal plants, which has attracted a lot of attention in recent decades due to its broad bioactive benefits including antioxidant, anti-cancer, anti-inflammatory, and antibacterial activity. ${ }^{40-45}$

The analysis results of the phenolic compounds showed that ginger tea showed greater phenolic content than temulawak. In line with this, the results of the flavonoid compounds analysis showed that ginger tea had more dominant levels of flavonoids. More specifically, emprit ginger has higher levels of total phenolic and flavonoids compounds than elephant ginger. The pharmacological activity of ginger is closely related to the presence of phenolic and flavonoids compounds in a fresh ginger rhizome, which includes 6-gingerol, 6-shogaol, and zingerone. Among the three, 6-gingerol was reported to be the most abundant bioactive compound in ginger with various pharmacological effects including antioxidant, analgesic, anti-inflammatory, and antipyretic properties. ${ }^{46-47}$ Zingerone compounds that are found in ginger essential oil are known to have antimicrobial activity ${ }^{48}$ Correspondingly, the phenolic compounds, xanthorrhizol, and curcuminoids in temulawak were also reported to produce antioxidant activity. ${ }^{49}$ Meanwhile, one of the elements of temulawak essential oil, namely terpenoids, produces antibacterial activity, which involves breaking down the membrane by lipophilic components. ${ }^{50}$

Table-2: Total Flavonoid \& Phenolic Compound of Herbal Teas

\begin{tabular}{c|c|c|c|c|c}
\hline \multirow{2}{*}{ Type } & $\begin{array}{c}\text { Total Flavonoid } \\
(\mathrm{mg} / 100 \mathrm{~g})\end{array}$ & $\begin{array}{c}\text { Total Phenolic } \\
(\mathrm{mg} / 100 \mathrm{~g})\end{array}$ & \multirow{2}{*}{$\mathrm{IC}_{50}(\mathrm{ppm})$} & \multicolumn{2}{|c}{ Inhibition Zone $(\mathrm{mm})$} \\
\cline { 5 - 6 } & 51.83 & 70.26 & 0.02116 & 11.06 & Escherichia coli \\
\hline $\mathrm{A}$ & 67.10 & 95.58 & 0.00912 & 11.15 & 9.21 \\
\hline $\mathrm{B}$ & 36.53 & 66.15 & 0.08785 & 11.58 & 10.38 \\
\hline $\mathrm{C}$ & &
\end{tabular}

\section{Antioxidant and Antimicrobial Activity}

The antioxidant in the chemical understanding is electron donor compounds. However, biologically the antioxidants definition has become broader, namely compounds that can reduce the negative impact of oxidants. ${ }^{51-52}$ The body needs antioxidants to protect cells from free radical damage. Antioxidants can donate electrons to free radical molecules, stabilizing free radicals and stopping chain reactions. Naturally, several types of plants are a source of antioxidants. Plant-based antioxidants are polyphenol/phenolic, flavonoid, cinnamic acid derivatives, coumarin, tocopherols, and organic acids. ${ }^{52-53}$ 
In general, ginger tea has a higher $\mathrm{IC}_{50}$ value than temulawak. Specifically, emprit ginger tea shows lower $\mathrm{IC}_{50}$ compared to elephant ginger tea. This indicates a better antioxidant activity of emprit ginger. This result is following the phenolic and flavonoid content of this tea which is higher than elephant ginger tea. Ginger and temulawak tea showed variable antimicrobial activity against Escherichia coli and Salmonella Typ (Table-2 and Figure-2). Escherichia coli is one of the microorganisms most often associated with food contamination. ${ }^{54-55}$ Escherichia coli is a gram-negative mesophilic bacteria, non-spore-forming, facultative, anaerobic, rod-shaped, grows in a temperature range of $7-45^{\circ} \mathrm{C}$. The presence of $E$. coli in food is an indicator of poor hygiene. The pathogenic strain of $E$. coli causes poisoning by creating toxins and causes gastroenteritis, kidney, and brain damage. ${ }^{56}$ While Salmonella is one of the foodborne gramnegative pathogens, in the form of rods and flagellates, which is one of the four main causes of world diarrhea disease.$^{57}$ Specifically, Salmonella Typ. is one type of Salmonella that may cause gastroenteritis, typhoid fever, and sepsis which can develop into serious illness and death in humans with an increased risk. ${ }^{58-59}$

Slightly different results were obtained in the analysis of antimicrobial activity, where temulawak showed its dominance by producing an inhibition zone of $11.58 \mathrm{~mm}$ against Escherichia coli and $10.37 \mathrm{~mm}$ against Salmonella typ. The antimicrobial activity shown by temulawak tea was not in line with the phenolic and flavonoid compounds. This indicates the presence of other functional compounds in temulawak which also have antimicrobial activity. Meanwhile, with an inhibition zone of $11.15 \mathrm{~mm}$ against E. coli and $9.58 \mathrm{~mm}$ against Salmonella Typ., emprit ginger tea showed better antimicrobial activity than elephant ginger tea with an inhibition zone of $11.06 \mathrm{~mm}$ and $9.21 \mathrm{~mm}$, respectively against E. coli and Salmonella Typ. This result is in line with the higher content of phenolic and flavonoids compounds in emprit ginger tea compared to elephant ginger tea.

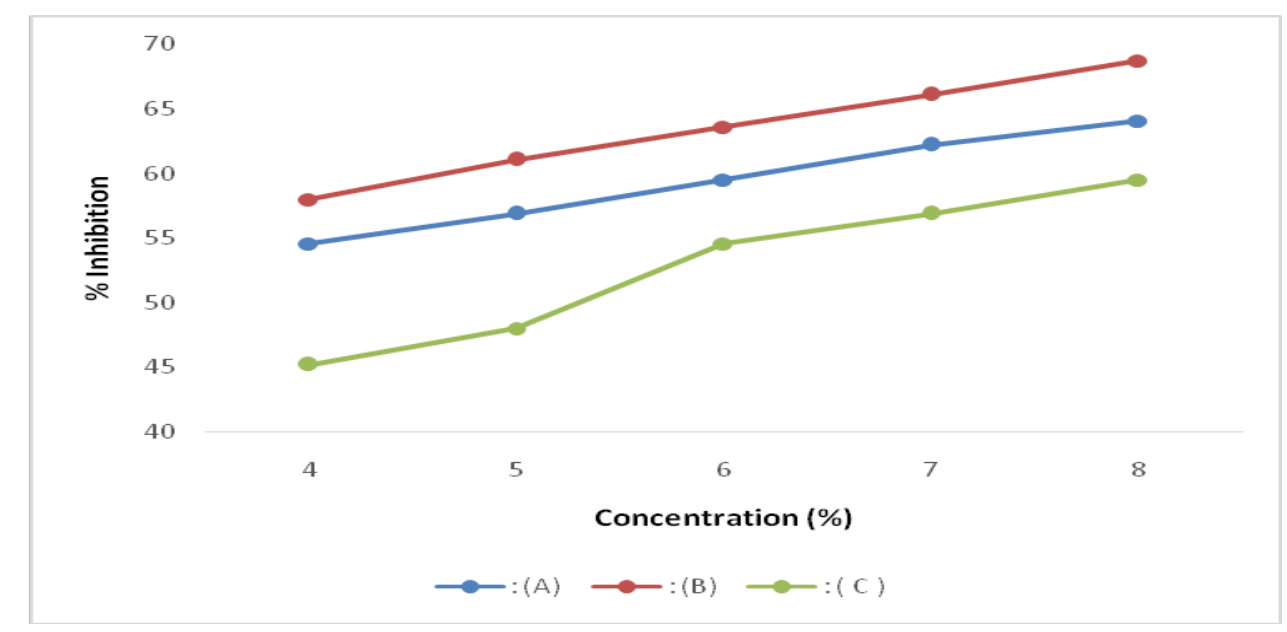

Fig.-1: Elephant Ginger (A); Emprit Ginger (B); and Temulawak (C) Tea Antioxidant Activity

\section{CONCLUSION}

Ginger-based herbal tea, both elephant and emprit, and temulawak have been made. The results of the analysis of organoleptic properties, proximate, crude fiber, phenolic, and flavonoids compounds levels, generally showed that emprit ginger herbal tea showed the best quality according to SNI 3836:2013. Antioxidant activity with $\mathrm{IC}_{50} 0.088-0.009 \mathrm{ppm}$ and antimicrobials activity, measured from the zone of inhibition in the range $11.06 \mathrm{~mm}-11.58 \mathrm{~mm}$ against Escherichia coli and $9.21 \mathrm{~mm}-10.37 \mathrm{~mm}$ against Salmonella Typ. indicate the high functional benefits of this herbal beverage, especially in preventing the further spread of COVID-19 infection.

\section{ACKNOWLEDGEMENT}

The authors would like to thank the Ministry of Education, Culture, Research and Technology of the Indonesia Republic for providing financial support for this research and to the Chemistry Department, Faculty of Mathematics and Natural Sciences, Universitas Negeri Surabaya for supporting facilities and infrastructure for this research. 
RASĀYAN J. Chem.

Vol. 14 | No. 3 |1920-1926| July - September | 2021

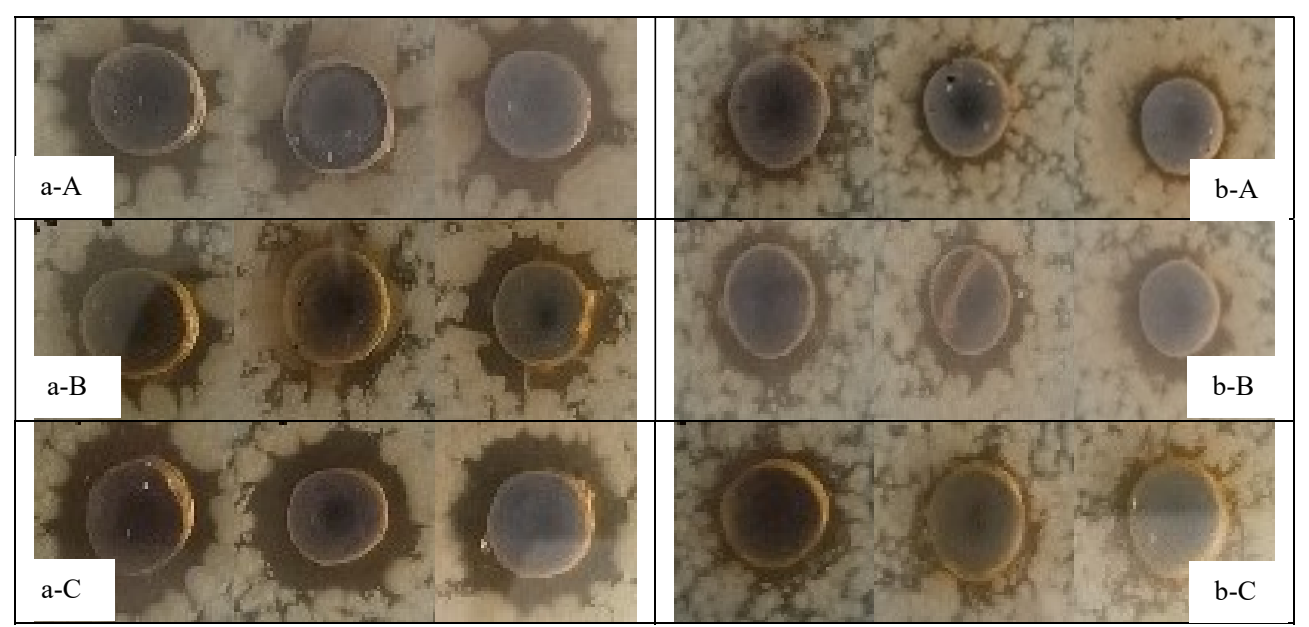

Fig.-2: (A) Elephant Ginger; (B)Emprit Ginger; and (C)Temulawak Antimicrobial Activity against (a) Escherichia coli and (b)Salmonella Thy

\section{REFERENCES}

1. N. Zhu, D. Zhang, W. Wang, X. Li, B. Yang, J. Song, New England Journal of Medicine, 382, 727(2020), https://doi.org/10.1056/NEJMoa2001017

2. Y. Jamilloux, T. Henry, A. Belot, S. Viel, M. Fauter, T. El Jammal, T. Walzer, B. Francois, P. Seve, Autoimmunity Reviews, 19(7), 102567(2020), https://doi.org/10.1016/j.autrev.2020.102567

3. R. Lu, X. Zhao, J. Li, P. Niu, B. Yang, H. Wu, W. Wang, H. Song, B. Huang, N. Zhu, Y. Bi, X. Ma, F. Zhan, L. Wang, T. Hu, H. Zhou, Z. Hu, W. Zhou, L. Zhao, J. Chen, Y. Meng, J. Wang, Y. Lin, J. Yuang, Z. Xie, J. Ma, W.J. Liu, D. Wang, W. Xu, E.C. Holmes, G.F. Gao, G. Wu, W. Chen, W. Shi, W. Tan, Lancet London England, 395, 565 (2020), https://doi.org/10.1016/S0140-6736(20)30251-8

4. F. Zhou, T. Yu, R. Du, G. Fan, Y. Liu, Z. Liu, Lancet London England, 395, 1054 (2020), https://doi.org/10.1016/S0140-6736(20)30566-3

5. G. Grasselli, A. Zangrillo, A. Zanella, M. Antonelli, L. Cabrini, A. Castelli, D. Cereda, A. Culuccello, G. Foti, R. Furnagalli, G. Lotti, N. Latronico, L. Lorini, S.Merler, G. Natalini, A. Piatti, M.V. Ranieri, A.M. Scandroglio, E. Storti, M. Cecconi, A. Pesenti, Journal of the American Medical Association, 323(16), 1574(2020), https://doi.org/10.1001/jama.2020.5394

6. X. Zhang, World Health Organization, WHO Traditional Medicine Strategy 2002-2005, Geneva (2002).

7. A.Y. Onaolapo, O.J. Onaolapo, 2019, Herbal Beverages and Brain Function in Health and Disease, in: Functional and Medicinal Beverages, Academic Press, Elsevier Inc., Netherland, pp. 324-326, https://doi.org/10.1128/iai.70.5.2249-2255.2002

8. K. Swarnalatha, C.H.V.K. Babu, B.H. Babu, RASAYAN Journal of Chemistry, 12(2), 907(2019), https://doi.org/10.31788/RJC.2019.1225168

9. K. Pyrzynska, A. Sentkowska, 2019, Herbal beverages as a source of antioxidant phenolics, in: Natural beverages, Academic Press, Elsevier Inc., Netherland, pp. 125-126, https://doi.org/10.1016/B978-0-12-816689-5.00005-5

10. K. Ghafoor, F. Al Juhaimi, M.M. Ozcan, N. Uslu, E.E. Babiker, I.A.M. Ahmed, I.U. Azmi, Lebensmittel-Wissenschaft Technologie - Food Science and Technology, 126, 109354(2020), https://doi.org/10.1111/jfpp.14980

11. H. Abral, J. Ariksa, M. Mahardika, D. Handayani, I. Aminah, N. Sandrawati, E. Sugiarti, A.N. Muslimin, S.D. Rosanti, Carbohydrate Polymers, 240, 116287(2020), https://doi.org/10.1016/j.carbpol.2020.116287

12. A.K. De, M. De, 2019, Functional and therapeutic applications of some important spices, in: The role of functional food security in global health, Academic Press, Elsevier Inc., Netherland, https://doi.org/10.1016/B978-0-12-813148-0.00029-3

13. K. Srinivasan, PharmaNutrition, 5, 18(2017), https://doi.org/10.1016/j.phanu.2017.01.001 
RASĀYAN J. Chem.

Vol. 14 | No. 3 |1920-1926| July - September | 2021

14. T. Awin, N. Buzgaia, S.Z.A. Ghafar, A. Mediani, S.M.M. Faudzi, M. Maulidiani, K. Shaari, F. Abas, Food Bioscience, 29, 126(2019), https://doi.org/10.1016/j.fbio.2019.04.009

15. N. Kusumawati, M.A. Anggarani, Rusijono, P. Setiarso, S. Muslim, International Journal on Advanced Science Engineering Information Technology, 7(1), 15(2017), https://doi.org/10.18517/ijaseit.7.1.910

16. P. Setiarso, Rusijono, Samik, N. Kusumawati, Advances in Engineering Research, 171, 56(2018), https://doi.org/10.2991/snk-18.2018.12

17. P. Setiarso, Rusijono, A. Bahar, Samik, N. Kusumawati, Atlantis Highlights in Chemistry and Pharmaceutical Sciences, 1, 55(2019), https://doi.org/10.2991/snk-19.2019.14

18. N. Akarchariya, S. Sirilun, J. Julsrigival, S. Chansakaowa, Asian Pacific Journal of Tropical Biomedicine, 7(10), 881(2017), https://doi.org/10.1016/j.apjtb.2017.09.009

19. J.Y. Cho, H.Y. Kim, H.M. Kim, H.N. Song, E. Hong, J-K. Hwang, H.S. Chun. Journal of Functional Foods, 30, 282(2017), https://doi.org/10.1016/j.jff.2017.01.020

20. N.H. Sairi, N. Muhammad, A.N. Pauzi, M.F.A. Bakar, B.Hj. A. Talip, N. Abdullah, L.B. Din, N. Ibrahim, Materials Today: Proceedings, 19, 1145(2019), https://doi.org/10.1016/j.matpr.2019.11.007

21. H-J. Lee, S-M. Kang, S-H. Jeong, K-H. Chung, B-I. Kim, Photodiagnosis and Photodynamic Therapy, 20, 116(2017), https://doi.org/10.1016/j.pdpdt.2017.09.003

22. T.Awin, A. Mediani, Maulidiani, S.W. Leong, S.M.M. Faudzi, K. Shaari, F. Abas, Journal of Food Composition and Analysis, 77, 66(2019), https://doi.org/10.1016/i.jfca.2019.01.004

23. R. Santhoshkumar, A. Yusuf, Biochemical Systematics and Ecology, 84, 21(2019), https://doi.org/10.1016/i.bse.2019.03.005

24. T. Boonsrangsom, South African Journal of Botany, 130, 1(2020), https://doi.org/10.1016/j.sajb.2020.01.005

25. W. Nurcholis, A.A. Munshif, L. Ambarsari, Brazilian Journal of Pharmacognosy, 28(1), 44(2018), https://doi.org/10.1016/j.bjp.2017.11.001

26. G. Wiranata, S. S. Yuwono, I. Purwantiningrum, Jurnal Pangan dan Agroindustri, 4(1), 449(2016).

27. T. Pujilestari, N. Lestari, Jurnal Riset Teknologi Industri, 3(6), 32(2009), https://doi.org/10.26578/jrti.v3i6.1424

28. N. Bermawie M. Rahardjo D. Wahyuno, Ma'mun, Status teknologi budidaya dan pasca panen tanaman kunyit dan temulawak sebagai penghasil kurkumin, ADOC Pub., Bogor, pp. 84-97(2008).

29. P. Anand, A.B. Kunnumakkara, R.A. Newman, B.B. Aggarwal, Journal of Molecular Pharmaceutics, 4(6), 807(2007), https://doi.org/10.1021/mp700113r

30. D.E. Dermawaty, Journal Majority, 4(1), 5(2015).

31. N.E. Husna, A. Asmawati, G. Surwajana, Jurnal Teknologi dan Industri Pertanian Indonesia, 6(3), 76(2014), https://doi.org/10.17969/jtipi.v6i3.2316

32. A. Maulana, Bachelor Thesis, Food Technology, Faculty of Engineering, Universitas Pasundan, Bandung (2016).

33. J.C. McDonald, G.M. Whitesides, Accounts of Chemical Research, 35(7), 491(2002), https://doi.org/10.1021/ar010110q

34. A. Dobos, B. Peter, J. Posta, L. Babinszky, Acta Agraria Debreceniensis, 2, 5(2019), https://doi.org/10.34101/actaagrar/2/3670

35. D.A.T. Southgate, 1986, Food components associated with dietary fiber, in: Spiller G. A. (ed.), Handbook of dietary fiber in human nutrition, CRC Press, Boca Raton, pp. 23-26.

36. S. H. HR. Nurung, Bachelor Thesis, Department of Pharmacy, Universitas Islam Negeri Alauddin, 2016.

37. D. Marinova, F. Ribarova, M. Atanassova, Journal of the University of Chemical Technology and Metallurgy, 40(3), 255(2005).

38. J. Kusnadi, Pengawet Alami Untuk Makanan, UB Press, Malang (2018).

39. K. Sayuti, R. Yenrina, Antioksidan alami dan sintetik, Andalas University Press, Padang (2015).

40. E. Lo Piparo, H. Scheib, N. Frei, G. Williamson, M. Grigorov, C.J. Chou, Journal of Medicinal Chemistry, 51(12), 3555(2008), https://doi.org/10.1021/jm800115x 
RASĀYAN J. Chem.

Vol. 14 | No. 3 |1920-1926| July - September | 2021

41. Y. Meng, A. Su, S. Yuan, H. Zhao, S. Tan, C. Hu, H. Deng, Y. Guo, Plant Foods for Human Nutrition, 71(4), 444(2016), https://doi.org/10.1007/s11130-016-0581-2

42. L. Ma, M. Zhang, B. Bhandari, Z. Gao, Trends in Food Science \& Technology, 64, 23(2017), https://doi.org/10.1016/j.tifs.2017.03.005

43. S.J. Maleki, J.F. Crespo, B. Cabanillas, Food Chemistry, 299, 125124(2019), https://doi.org/10.1016/j.foodchem.2019.125124

44. Y. Huang, P. Wu, J. Ying, Z. Dong, X. D. Chen, Food Chemistry, 128610(2020), https://doi.org/10.1016/j.foodchem.2020.128610

45. M. Simorangkir, W. Hutabarat, B. Nainggolan, S. Silaban, RASAYAN Journal of Chemistry, 12(2), 959(2019), https://doi.org/10.31788/RJC.2019.1225095

46. S. Dugasani, M.R. Pichika, V.D. Nadarajah, M.K. Balijepalli, Journal of Ethnopharmacology, 127(2), 515(2010), https://doi.org/10.1016/j.jep.2009.10.004

47. J.K. Kundu, H-K. Na, Y-J. Surh, Forum of Nutrition, 61, 182(2009), https://doi.org/10.1159/000212750

48. Supriyanto, B. Cahyono, Chemistry Progress, 5(2), 81(2012), https://doi.org/10.35799/cp.5.2.2012.771

49. W. Nurcholis, Jurnal Jamu Indonesia, 2(1), 25(2017), https://doi.org/10.29244/jii.v2i1.27

50. A.R. Mashita, Saintika Medika, 10(2), 138(2017), https://doi.org/10.22219/sm.v10i2.418

51. S. Winarti, Makanan Fungsional, Graha Ilmu, Yogyakarta (2010).

52. T.T. Irianti, Sugiyanto, S. Nuranto, M. Kuswandi, Antioksidant, Universitas Gajah Mada, Yogyakarta (2017).;

53. D.G.R. Aruan, T. Barus, G. Haro, P. Simanjuntak, RASAYAN Journal of Chemistry, 12(2), 947(2019), https://doi.org/10.31788/RJC.2019.1225204

54. S. de Oliveira Elias, T.B. Noronha, E.C. Tondo, Food Microbiology, 84, 103217(2019), https://doi.org//10.1016/j.fm.2019.05.001

55. D. Alves, M.A. Cerqueira, L.M. Pastrana, S. Sillankorva, Food Research International, 128, 108791(2020), https://doi.org/10.1016/j.foodres.2019.108791

56. G. Ekici, E. Dumen, 2018, Escherichia sa and food safety, in: The universe of Escherichia coli, intechopen, England, https://doi.org/10.5772/intechopen.82375

57. https://www.who.int/news-room/fact-sheets/detail/salmonella-(non-typhoidal).

58. P. Antunes, J. Mourao, J. Campos, L. Peixe, Clinical Microbiology and Infectious, 22, 110(2016), https://doi.org/10.1016/j.cmi.2015.12.004

59. W. Rabsch, H.L.Andrews, R.A.Kingsley, R. Prager, H. Tschäpe, L.G. Adams et al., Infection and Immunity, 70(5), 2249(2002), https://doi.org/10.1128/iai.70.5.2249-2255.2002

[RJC-6331/2020] 